\title{
Pengaruh model problem based learning terhadap kemampuan C1-C4 kelas XI MIA materi sistem ekskresi manusia
}

\author{
Erlita Ambarwati 1*, Destri Ratna Ma'rifah ${ }^{2}$ \\ Pendidikan Biologi, Fakultas Keguruan dan Ilmu Pendidikan, Universitas Ahmad Dahlan \\ Jl. Jendral Ahmad Yani (Ringroad Selatan) Tamanan, Banguntapan, Bantul \\ Daerah Istimewa Yogyakarta 55191 \\ 1 erlitaambarwati06@gmail.com*; 2 destrirm@pbio.uad.ac.id \\ *korespondensi penulis
}

\begin{abstract}
Abstrak
Penyampaian materi pada pembelajaran biologi masih didominasi dengan ceramah dilanjutkan pemberian tugas. Siswa hanya mencatat apa yang disampaikan guru dan beranggapan bahwa mata pelajaran biologi sulit dipahami sehingga hasil belajar belum mencapai KKM. Pembelajaran dengan model PBL, siswa diharapkan lebih memahami materi dan memecahkan permasalahan yang berkaitan dengan kehidupan nyata. Penelitian ini bertujuan untuk mengetahui pengaruh penerapan model PBL terhadap kemampuan C1-C4 siswa kelas XI MIA SMA Muhammadiyah 1 Prambanan pada materi sistem ekskresi manusia. Jenis penelitian ini adalah kuasi eksperimen dengan desain Nonequivalent Control Group Design. Populasi dalam penelitian adalah siswa kelas XI SMA Muhammadiyah 1 Prambanan T.A 2018/2019. Sampel dalam penelitian ini yaitu kelas eksperimen XI MIA 1 dan kelas kontrol XI MIA 3 dengan menggunakan teknik purposive sampling. Teknik pengumpulan data berupa tes dan instrumen penelitian berupa soal pilihan ganda. Teknik analisis data berupa deskriptif kuantitatif. Hasil analisis Normalized-Gain kemampuan C1-C4 dengan uji Independent sampel t-test menunjukkan terdapat perbedaan kemampuan kognitif siswa kelas kontrol dan kelas eksperimen. Hal ini menunjukkan bahwa penerapan model Problem Based Learning berpengaruh terhadap kemampuan C1-C4 pada siswa kelas XI MIA SMA Muhammadiyah 1 Prambanan materi sistem ekskresi manusia.
\end{abstract}

Kata kunci: Problem Based Learning (PBL), kemampuan C1-C4, sistem ekskresi manusia.

\section{Abstract}

Delivery of material on biology learning is still dominated by lectures followed by giving assignments. That students only record what the teacher conveyed and assume that biology subjects are difficult to understand so that learning outcomes have not yet reached KKM. Learning with the PBL model, students are expected to better understand the material and solve problems related to real life. This study aims to determine the effect of the application of the PBL model on the competence of $\mathrm{C} 1-\mathrm{C} 4$ students in class XI MIA SMA Muhammadiyah 1 Prambanan on human excretion system. This type of research is a quasi- experimental design with Nonequivalent Control Group Design. The population in the study was a class XI student at SMA Muhammadiyah 1 Prambanan T.A 2018/2019. The sample in this study is the experimental class XI MIA 1 and the XI MIA 3 control class using purposive sampling technique. Data collection techniques in the form of tests and the research instruments were multiple choice questions. The 
data analysis technique is descriptive quantitative. The Normalized-Gain analysis of the competence of C1-C4 with the Independent sample t-test showed there were differences in cognitive abilities of the control class students and the experimental class. This shows that the application of the Problem Based Learning model has an effect on C1-C4 competence on the XI MIA students of SMA Muhammadiyah 1 Prambanan material in the human excretion system.

Keywords: Problem Based Learning (PBL), competence C1-C4, human excretion system.

\section{PENDAHULUAN}

Pendidikan merupakan faktor utama dalam pembentukan pribadi manusia sehingga diharapkan dapat membentuk insan yang berkualitas dan mampu bersaing di era global saat ini. Berdasarkan data Education For Global Monitoring Report 2012 oleh UNESCO setiap tahunnya menunjukkan bahwa pendidikan Indonesia berada di peringkat ke-64 dari 120 negara, sedangkan menurut data Education Development Index (EDI), pendidikan di Indonesia berada pada peringkat ke-69 dari 127 negara pada tahun 2011 (Harahap, 2013: 1).

Berdasarkan data UNESCO dan EDI, maka kualitas pendidikan di Indonesia tergolong rendah dibandingkan dengan negara lain. Upaya terus dilakukan pemerintah Indonesia untuk memperbaiki kualitas pendidikan, salah satunya dengan cara menerapkan pembelajaran berbasis Kurikulum 2013. Kurikulum 2013 menerapkan pembelajaran berbasis aktivitas, yang diharapkan akan menghasilkan insan Indonesia yang produktif, kreatif, inovatif, dan afektif melalui penguatan sikap, pengetahuan, dan keterampilan yang terintegrasi (Dikdasmen, 2015: 24).

Kurikulum 2013 diharapkan mampu memperbaiki pendidikan di Indonesia melalui proses pembelajaran yang lebih baik. Keberhasilan proses pembelajaran tidak terlepas dari kegiatan belajar mengajar di dalam kelas. Proses belajar siswa melibatkan kegiatan seperti mengobservasi, mengumpulkan data, menganalisis masalah serta mampu berpikir kritis (Noviar \& Hastuti, 2015: 44). Kegiatan belajar mengajar di dalam kelas tentunya harus ada proses interaksi dan hubungan timbal balik antara guru dengan siswa, agar proses pembelajaran berjalan optimal.

Berdasarkan hasil observasi selama magang terapan pada bulan Agustus 2018 di SMA Muhammadiyah 1 Prambanan, pembelajaran biologi masih didominasi penyampaian materi oleh guru dengan metode ceramah, guru kurang mengaitkan materi pelajaran dengan permasalahan dalam kehidupan nyata, kemudian dilanjutkan pemberian tugas. Hal tersebut menjadikan siswa hanya mencatat apa yang disampaikan guru dan tidak bertanya meskipun 
belum memahami materi sehingga kurang adanya interaksi antara guru dan siswa. Saat pembelajaran berlangsung masih banyak siswa yang tidak memperhatikan penjelasan guru yang ditandai dengan mereka cenderung sibuk sendiri dengan teman sebangkunya, 50\% bermain handphone, dan melakukan kegiatan lain yang tidak berkaitan dengan pembelajaran.

Berdasarkan hasil wawancara pada bulan Agustus 2019 di SMA Muhammadiyah 1 Prambanan, siswa kelas XI beranggapan bahwa mata pelajaran biologi itu sulit dipahami. Salah satu materi pelajaran biologi yang dipelajari kelas XI MIA semester genap adalah sistem ekskresi manusia. Kompetensi dasar dari materi sistem ekskresi manusia yaitu menganalisis hubungan antara struktur jaringan penyusun organ pada sistem ekskresi manusia dalam kaitannya dengan bioproses dan gangguan fungsi yang dapat terjadi pada sistem ekskresi manusia. Kompetensi dasar pada materi sistem ekskresi manusia meminta peserta didik untuk mencapai ranah kognitif tingkat C4 (menganalisis). Menurut Sani (2016: 102), tingkat pemahaman $\mathrm{C} 4$ (menganalisis) termasuk kemampuan berpikir tingkat tinggi (Higher Order Thinking Skills). Materi sistem ekskresi manusia menuntut siswa untuk mampu mengaitkan antar suatu organ dengan organ yang lain sehingga menciptakan suatu sistem kerja baik secara fisik maupun fungsional.

Berdasarkan nilai ulangan harian, rata-rata materi sistem pencernaan makanan sebesar 73,42; sistem pernapasan sebesar 75,71; sistem ekskresi sebesar 53,60; sistem koordinasi sebesar 66,10; dan sistem reproduksi sebesar 79,42. Berdasarkan nilai ulangan harian, maka materi sistem ekskresi manusia di kelas XI MIA 1 memiliki rata-rata yang paling rendah diantara materi pada semester genap dan masih belum mencapai Kriteria Ketuntasan Minimal (KKM). Hal ini dibuktikan dengan rata-rata nilai ulangan harian kelas XI MIA 1 T.A 2017/2018 adalah 53,6 untuk materi sistem ekskresi manusia sedangkan KKM mata pelajaran biologi T.A 2018/2019 adalah 70. Dari 28 siswa, hanya 1 siswa yang mampu mencapai KKM sedangkan 27 siswa yang lainnya masih di bawah KKM. Hal ini terjadi karena pemahaman siswa tentang materi sistem ekskresi manusia masih kurang. Menurut Arikunto (2009: 62), tingkat pencapaian untuk tes formatif adalah $75 \%$, siswa yang belum mencapai skor $75 \%$ dari skor yang diharapkan wajib menempuh kegiatan perbaikan (remedial program). Tingkat pencapaian materi minimal $75 \%$ artinya siswa yang bersangkutan harus mencapai skor $75 \%$ dari skor maksimal yang ditetapkan.

Berdasarkan hasil observasi pada bulan Agustus 2018 di SMA Muhammadiyah 1 Prambanan, maka guru perlu mengupayakan suatu cara yaitu melakukan pembelajaran yang berpusat pada siswa sehingga siswa dapat lebih mudah mempelajari konsep materi sistem ekskresi manusia dan mengaitkannya dalam kehidupan nyata. Pembelajaran yang mengaitkan 
dengan kehidupan nyata menekankan proses keterlibatan siswa secara penuh untuk dapat menemukan materi yang dipelajari dan menghubungkan dengan situasi kehidupan sehari-hari sehingga siswa dapat menerapkan dalam kehidupannya. Salah satu model pembelajaran yang dapat diupayakan yaitu model Problem Based Learning (PBL) atau pembelajaran berbasis masalah.

Menurut Keziah (2010: 129) model Problem Based Learning adalah model pembelajaran yang berpusat pada siswa, menekankan proses kolaboratif memecahkan masalah dan mencerminkan pengalaman mereka. Hal tersebut sejalan dengan penelitian yang dilakukan oleh Argaw, et al (2010: 858) didapatkan hasil bahwa model Problem Based Learning dapat meningkatkan kemampuan pemecahan masalah. Pembelajaran dengan model Problem Based Learning, diharapkan membuat siswa merasa penasaran terhadap suatu permasalahan sehingga siswa berupaya untuk memecahkan permasalahan yang diberikan.

Model Problem Based Learning diharapkan mampu membuat siswa memahami konsep dari materi sistem ekskresi manusia dan memecahkan permasalahan yang berkaitan dengan materi dalam kehidupan nyata. Hasil penelitian terdahulu yang dilakukan oleh Phumeechanya \& Wannapiroon (2013: 197) menunjukkan hasil bahwa dengan penerapan proses pembelajaran berbasis masalah berpengaruh terhadap kemampuan memecahkan masalah. Penelitian yang dilakukan oleh Ernawati (2016: 59) menunjukkan bahwa model Problem Based Learning berpengaruh terhadap hasil belajar siswa pada konsep jaringan tumbuhan. Berdasarkan berbagai permasalahan di atas, peneliti ingin melakukan penelitian dengan judul "Pengaruh Model Problem Based Learning terhadap Kemampuan C1-C4 Siswa Kelas XI MIA SMA Muhammadiyah 1 Prambanan pada Materi Sistem Ekskresi Manusia”. Jadi tujuan dari penelitian ini adalah untuk mengetahui pengaruh penerapan model Problem Based Learning terhadap kemampuan C1-C4 siswa kelas XI MIA SMA Muhammadiyah 1 Prambanan pada materi sistem ekskresi manusia.

Kajian penelitian yang relevan dengan penelitian ini yaitu penelitian yang dilakukan oleh Ernawati tahun 2016 tentang kuasi eksperimen dengan judul "Pengaruh Model Problem Based Learning (PBL) terhadap Hasil Belajar Siswa pada Konsep Jaringan Tumbuhan" menunjukkan bahwa terdapat pengaruh model Problem Based Learning terhadap hasil belajar siswa pada konsep jaringan tumbuhan. Hasil belajar siswa dengan model Problem Based Learning lebih tinggi dibandingkan dengan model pembelajaran konvensional (diskusi dan tanya jawab). Penelitian yang dilakukan oleh Herlina, Kasim, dan Mamu tahun 2016 tentang kuasi eksperimen yang berjudul "Pengaruh Model Problem Based Learning dan Motivasi 
Berprestasi terhadap Hasil Belajar Siswa pada Mata Pelajaran Biologi di Kelas XI IPA MAN 2 Model Palu" menunjukkan bahwa model Problem Based Learning berpengaruh secara signifikansi terhadap hasil belajar siswa. Penelitian yang dilakukan memiliki perbedaan dengan penelitian relevan sebelumnya. Perbedaan tersebut terletak pada aspek yang diteliti. Penelitian relevan aspek yang diteliti adalah materi jaringan tumbuhan dan hasil belajar secara umum. Penelitian ini meneliti aspek tentang materi sistem ekskresi manusia dan kemampuan C1-C4 siswa.

\section{METODE}

Jenis penelitian ini adalah kuasi eksperimen dengan desain Nonequivalent Control Group Design. Populasi dalam penelitian adalah siswa kelas XI SMA Muhammadiyah 1 Prambanan T.A 2018/2019. Sampel dalam penelitian ini yaitu kelas eksperimen XI MIA 1 dan kelas kontrol XI MIA 3 dengan menggunakan teknik purposive sampling. Teknik pengumpulan data berupa tes dan instrumen penelitian berupa soal pilihan ganda. Teknik analisis data berupa deskriptif kuantitatif.

\section{HASIL DAN PEMBAHASAN}

Penelitian yang telah dilakukan termasuk jenis penelitian kuasi eksperimen pada mata pelajaran biologi materi sistem ekskresi manusia. Penelitian ini dilakukan di SMA Muhammadiyah 1 Prambanan pada kelas XI MIA 1 sebagai kelas eksperimen sebanyak 22 siswa dan XI MIA 3 sebagai kelas kontrol sebanyak 20 siswa pada Semester Genap Tahun Ajaran 2018/2019. Berikut ini adalah hasil penelitian dan pembahasan yang dilakukan tanggal 13 Maret sampai 21 Maret 2019.

\section{Hasil Kemampuan C1-C4}

Berikut adalah diagram perbandingan kemampuan $\mathrm{C} 1-\mathrm{C} 4$ pada kelas eksperimen dan kontrol.

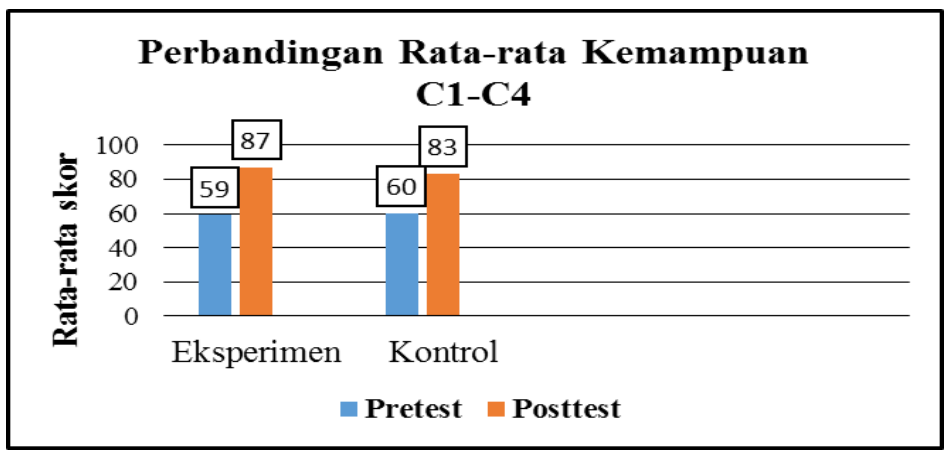

Gambar 1. Perbandingan kemampuan C1-C4 
Berdasarkan data pada gambar 1. terlihat bahwa rata-rata pretest kelas eksperimen 59 dan kelas kontrol 60, sedangkan rata-rata posttest kelas eksperimen 87 dan kelas kontrol 83 sehingga kemampuan $\mathrm{C} 1-\mathrm{C} 4$ pada kelas eksperimen dengan pembelajaran menggunakan model Problem Based Learning lebih tinggi daripada kelas kontrol. Analisis data kemampuan C1-C4 dilakukan dengan uji hipotesis menggunakan uji parametrik yaitu uji Independent Sampel $t$ Test. Uji ini dilakukan untuk menguji apakah terdapat perbedaan rata-rata 2 (dua) sampel yang tidak berhubungan (bebas). Sampel tersebut adalah nilai Normalized-Gain kemampuan $\mathrm{C} 1-\mathrm{C} 4$ siswa.

Hipotesis:

Ho: Tidak terdapat perbedaan kemampuan C1-C4 kelas kontrol dan eksperimen

Ha: Terdapat perbedaan kemampuan C1-C4 kelas kontrol dan eksperimen

Dengan kriteria pengujian menurut Santoso (2015: 39) yaitu:

Jika nilai signifikansi > 0,05 maka Ho diterima dan Ha ditolak

Jika nilai signifikansi $<0,05$ maka Ho ditolak dan Ha diterima

Tabel 1. Hasil uji independent sampel t-test $N$-Gain kemampuan C1-C4

\begin{tabular}{|c|c|c|c|c|c|c|c|c|}
\hline \multirow[t]{2}{*}{$\mathbf{F}$} & \multirow[t]{2}{*}{ Sig. } & \multirow[t]{2}{*}{$\mathbf{T}$} & \multirow[t]{2}{*}{ Df } & \multirow[t]{2}{*}{$\begin{array}{l}\text { Sig. (2- } \\
\text { tailed) }\end{array}$} & \multirow[t]{2}{*}{$\begin{array}{c}\text { Mean } \\
\text { Differenc e }\end{array}$} & \multirow[t]{2}{*}{$\begin{array}{l}\text { Std. Error } \\
\text { Differenc e }\end{array}$} & \multicolumn{2}{|c|}{$\begin{array}{l}95 \% \text { Confidence } \\
\text { Interval of the } \\
\text { Difference }\end{array}$} \\
\hline & & & & & & & Lower & Upper \\
\hline $\begin{array}{l}0,1 \\
71\end{array}$ & $\begin{array}{l}0,6 \\
81\end{array}$ & $\begin{array}{l}3,1 \\
29 \\
3,1 \\
30\end{array}$ & $\begin{array}{c}40 \\
39,68 \\
7\end{array}$ & 0,003 & 0,13974 & 0,04465 & $\begin{array}{c}0,049 \\
47 \\
0,049 \\
48\end{array}$ & $\begin{array}{c}0,2300 \\
2 \\
0,2300 \\
0\end{array}$ \\
\hline
\end{tabular}

Hasil Uji Independent Sampel T-Test $N$-Gain kemampuan C1-C4 diperoleh nilai signifikansi yaitu 0,003 sehingga lebih kecil dari taraf signikansi 0,05, maka Ho ditolak dan dapat disimpulkan bahwa terdapat perbedaan yang signifikan antara kemampuan kognitif siswa kelas kontrol dan kelas eksperimen. Lebih singkatnya, model Problem Based Learning berpengaruh terhadap kemampuan $\mathrm{C} 1-\mathrm{C} 4$ siswa kelas XI MIA SMA Muhammadiyah 1 Prambanan pada materi sistem ekskresi manusia.

Karakteristik materi sistem ekskresi manusia menekankan pada proses pembelajaran kontekstual. Hal ini dilihat dari kompetensi dasar yang menekankan siswa untuk menghubungkan materi dengan kejadian yang berkaitan dalam kehidupan sehari-hari termasuk kesehatan manusia sehingga siswa lebih memahami materi. Hal tersebut diperkuat oleh teori Putra (2013: 65), bahwa Problem Based Learning adalah model pembelajaran yang menggunakan masalah dunia nyata sebagai konteks bagi siswa untuk belajar tentang cara 
berpikir kritis dan keterampilan pemecahan masalah, serta untuk memperoleh pengetahuan dan konsep yang esensial dari materi pelajaran. Berdasarkan penjelasan di atas, maka model Problem Based Learning dapat diterapkan untuk materi sistem ekskresi manusia dikarenakan karakteristik materi sistem ekskresi manusia yang menekankan pada proses pembelajaran kontekstual.

\section{SIMPULAN}

Berdasarkan hasil penelitian Pengaruh Model Problem Based Learning terhadap Kemampuan C1-C4 Kelas XI MIA Materi Sistem Ekskresi Manusia dapat disimpulkan bahwa penerapan model Problem Based Learning berpengaruh terhadap kemampuan C1-C4 siswa kelas XI MIA SMA Muhammadiyah 1 Prambanan pada materi sistem ekskresi manusia.

\section{REFERENSI}

Argaw, Aweke S., Haile, Beyene B., Ayelaw, Beyene T., Kuma, Shiferaw G. 2016. The Effect of Problem Based Learning (PBL) Instruction on Students Motivation and Problem Solving Skills of Physics. EURASIA Journal of Mathematics Science and Technology Education.

Arikunto, Suharsimi. 2009. Dasar-dasar Evaluasi Pendidikan. Jakarta: Rineka Cipta. Direktorat Jenderal Pendidikan Dasar dan Menengah. 2015. Panduan Penilaian untuk Sekolah Menengah Atas. Jakarta: Kementerian Pendidikan dan Kebudayaan.

Ernawati, Henny. 2016. Pengaruh Model Problem Based Learning (PBL) terhadap Hasil Belajar Siswa pada Konsep Jaringan Tumbuhan. Skripsi. Jakarta: Universitas Islam Negeri Syarif Hidayatullah.

Harahap, R. F. 01 Juni. 2013. “Astaga, RI Peringkat ke 64 untuk Pendidikan.” Okezone. Hlm 1.

Herlina, Amiruddin Kasim, dan Hartono D. Mamu. 2016. Pengaruh Model Problem Based Learning dan Motivasi Berprestasi terhadap Hasil Belajar Siswa pada Mata Pelajaran Biologi di Kelas XI IPA MAN 2 Model Palu. Jurnal Sains dan Teknologi Tadulako. Vol. 5, No. 1, Januari 2016, hal 11-18.

Keziah, A. 2010. A Comparative Study Of Problem Based And Lecture Based Learning In Secondary School Students. Internationa Journal of Science and Technology Education Research. Vol. 1(6).

Noviar, D., \& Hastuti, D. W. I. R. 2015. Pengaruh Model Problem Based Learning (PBL) Berbasis Scientific Approach terhadap Hasil Belajar Biologi Siswa Kelas X di SMA N 2 Banguntapan T. A. 2014/2015. Jurnal Bioedukasi.Vol. 8, No. 2: 42-47.

Phumeechanya, N., \& Wannapiroon, P. 2013. Development of a Ubiquitos Learning System with Scaffolding and Problem-Based Learning Model to Enhance Problem-Solving Skills and ICT Literacy. International Journal of e-Education, e-Business, $e$ Management and e-Learning, Vol.3, No. 3, June 2013. 
Putra, Sitiatava Rizema. 2013. Desain Evaluasi Belajar Berbasis Kinerja. Jogjakarta: DIVA Press.

Sani, Ridwan Abdullah. 2016. Penilaian Autentik. Jakarta: Bumi Aksara. 